\title{
Alzheimer culprits: cellular crossroads and interplay
}

\author{
Sylvie Claeysen ${ }^{\mathrm{a}, \mathrm{b}, \mathrm{c}^{*}}$, Maud Cochet ${ }^{\mathrm{a}, \mathrm{b}, \mathrm{c}}$, Romain Donneger ${ }^{\mathrm{a}, \mathrm{b}, \mathrm{c}}$, Aline Dumuis ${ }^{\mathrm{a}, \mathrm{b}, \mathrm{c}}$, Joël \\ Bockaert $^{\mathrm{a}, \mathrm{b}, \mathrm{c}}$ and Patrizia Giannoni ${ }^{\mathrm{a}, \mathrm{b}, \mathrm{c}}$
}

${ }^{a}$ CNRS, UMR-5203, Institut de Génomique Fonctionnelle, F-34000 Montpellier, France

${ }^{\mathrm{b}}$ Inserm, U661, F-34000 Montpellier, France

${ }^{\mathrm{c}}$ Universités de Montpellier 1 \& 2, UMR-5203, F-34000 Montpellier, France

* Corresponding author: Sylvie Claeysen, Institut de Génomique Fonctionnelle, 141 Rue de la Cardonille, Montpellier Cedex 5, F-34094, France. Tel: (+33) 4343592 15. Fax: (+33) 467 5424 32. Email address: sylvie.claeysen@igf.cnrs.fr

\begin{abstract}
Alzheimer's disease (AD) is the primary cause of dementia in the elderly and one of the major health problems worldwide. Since its first description by Alois Alzheimer in 1907, noticeable but insufficient scientific comprehension of this complex pathology have been achieved. All the research that has been pursued takes origin from the identification of the pathological hallmarks in the forms of amyloid- $\beta$ (A $\beta)$ deposits (plaques), and aggregated hyperphosphorylated tau protein filaments (named neurofibrillary tangles). Since this discovery, many hypotheses have been proposed to explain the origin of the pathology. The "amyloid cascade hypothesis" is the most accredited theory. The mechanism suggested to be one of the initial causes of AD is an imbalance between the production and the clearance of A $\beta$ peptides. Therefore, Amyloid Precursor Protein (APP) synthesis, trafficking and metabolism producing either the toxic $\mathrm{A} \beta$ peptide via the amyloidogenic pathway or the sAPP $\alpha$ fragment via the non amyloidogenic pathway have become appealing subjects of study. Being able to reduce the formation of the toxic $A \beta$ peptides is obviously an immediate approach in the trial to prevent $\mathrm{AD}$. The following review summarizes the most relevant discoveries in the field of the last decades.
\end{abstract}

\section{Keywords}

Alzheimer's disease; amyloid precursor protein; amyloidogenic pathway; secretase; G protein-coupled receptor 


\section{Introduction}

Alzheimer's disease (AD) is a highly debilitating neurodegenerative disorder that afflicts millions of people and has reached in our society an enormous impact. The number of patients increases every year and recent projections predict 65 millions of $\mathrm{AD}$ cases worldwide by 2030 (www.alzforum.org), and even more in the early pre-diagnosis stages. Researchers from academic and pharmaceutical industries, political leaders, and the general population urge finding a solution to stop the constant increase of affected AD patients. Thus, many efforts have been done to reach a comprehensive understanding of the mechanisms of the pathology development. In AD research history, few observations are considered as milestones. One is the identification of extracellular amyloid- $\beta(A \beta)$ aggregates, referred to as plaques when present in the gray matter and Cerebral Amyloid Angiopathy (CAA) when present in vessels. Another is the identification of intracellular filaments of hyperphosphorylated tau protein, named tangles [1-3]. It's from these observations that the majority of the research plans are taking their origin and inspiration. Finally, a third one is the discovery that $5 \%$ of the estimated AD cases are familial and hereditary (FAD). Genetic studies identified mutations in the Amyloid Precursor Protein (APP) and in enzymes involved in its cleavage (PS1 and PS2, part of the $\gamma$-secretase complex) as the causes of these genetically determined cases of AD occurring early in life $[4,5]$. For the majority of $\mathrm{AD}$ cases instead, referred to as sporadic $\mathrm{AD}$, only "risk factors" have been identified, like age (the probability of developing AD increases from $10 \%$ under the age of 65 to $50 \%$ over 85), the presence of the Apolipoprotein E4 allele (instead of the most common E3, or E2), a protein involved in the clearance of $A \beta[6,7]$ and few others recently discovered like PICALM, clusterin and CR1 [8]. Taking together these and related observations led to the hypothesis that $\mathrm{A} \beta$ accumulation is the primarily culprit driving the development of AD. For a long time, only an increase in synthesis and/or decrease degradation of $A \beta$ were taken into consideration but later on an impaired clearance started to be also considered. It is likely that all these events have a part of responsibility. This hypothesis has been developed as the "amyloid cascade hypothesis" of AD and is nowadays the most accredited one. According to this theory, Amyloid Precursor Protein (APP) has thus a prominent role in AD and has obviously become the object of numerous studies. Several of them underline how APP processing modulation might be the key target in the battle against AD. The present review will focus on cellular trafficking and processing of APP. We will describe the different enzymes (secretases) involved, the cellular compartments where the cleavage takes place as well as the proteins interacting either with APP and secretases that might affect those processes.

\section{APP processing}

Once synthesized and post-translationally modified, APP in its mature form can be processed by at least two proteolytic pathways, the so-called "non-amyloidogenic" and the "amyloidogenic" pathways (Fig. 1). While, in the first pathway, we have an implication of enzymes which cleave APP within the A $\beta$ sequence ( $\alpha$-secretases), thus impeding the formation of the toxic $A \beta$ peptide, in the second one, we have the formation of $A \beta$, mainly to 40 and 42 amino acids (aa) long peptides (although 37 to 43 aa forms are also produced). Since the identification of this processing mechanism, trying to modulate the shedding of APP by stimulating the non-amyloidogenic pathway had a prominent role in AD research. Thanks to the great number of studies performed, we currently know many biochemical characteristics and cellular localisation properties of APP and secretases. The interplay 
between the localisation of APP and $\alpha-, \beta$-, and $\gamma$-secretase is determining the degree of A $\beta$ production. The intracellular localisation and trafficking of APP is complicated with APP found variously at the Golgi, trans-Golgi network (TGN), endosomes and plasma membrane. Moreover, the secretases involved can also be found in various sub-cellular compartments. We will first describe the main characteristics and residence of these enzymes, then trying to integrate their functions with APP trafficking.

\section{3. $\alpha$-Secretase and the non amyloidogenic pathway}

Several transmembrane proteases belonging to the metalloproteases have been proposed to act as $\alpha$-secretases. The most accredited enzymes for this role are the members of the $\mathrm{A}$ Disintegrin And Metalloprotease (ADAM) family, ADAM 9, 10 and 17 [9-11]1. $\alpha$-secretase cleavage gives origin to the sAPP $\alpha$ fragments and a C-terminal fragment (C83 or $\alpha-\mathrm{CTF})$ that remains anchored to the membrane. $\alpha$-secretase action can be constitutive or stimulated ("regulated $\alpha$-cleavage") by different agents, like drugs activating PKC and some GPCRs [1115], reviewed by [16]. It has been demonstrated that while ADAM17 and 9 are mostly accountable for a regulated cleavage, ADAM10 is part of both processes and it is definitely the major ADAM family member responsible of constitutive activity in neurons [11]. A relevant difference among these proteases is their level of expression in brain. While ADAM10 is in fact highly expressed in this organ, ADAM9 [17], and ADAM17 [18, 19] are found only at low concentrations. It is currently known that ADAM10 is synthesized in the Endoplasmic Reticulum (ER) as proenzyme, is mostly present in this form in the Golgi at steady state [12], but it is found in its mature form at cell surface. Parvathy and colleagues demonstrated that in neurons, $\alpha$-secretase activity is present mostly at the cell surface [20]. Several studies demonstrated that, although some $\alpha$-secretase activity is present in the TGN, this represents a minor part respect to the activity at the cell surface [21-23]. A gene on chromosome 15 is encoding for this 750 aa long protease [24] that, being a zymogen, needs the removal of the prodomain to be activated [25] (Fig. 2) and, like the other members of the ADAM family, requires a zinc ion. Between the prodomain and the catalytic region there is a consensus sequence (RKKR) recognized by a proprotein convertase (PC7) and/or furin. It is not clear whether or not the conjunction between these two membrane-associated calciumdependant endoproteinases (PC7 and furin) is required to cleave ADAM10 prodomain unmasking its active site [26, 27] (Table 1). Already in 2001 Anders and colleagues showed that a mutation in the site recognized by PC7 was able to inhibit ADAM10 activation [28]. The prodomain has a fundamental role in maintaining ADAM10 inactive and for its protection from degradation along the secretory pathway [9, 25, 29]. It can also coordinate the zinc ion localization at the active catalytic site. Interestingly, it has been reported that mutations in the region encoding for the prodomain sequence in ADAM10 gene [30] could be responsible for late-onset AD. Following the catalytic domain, ADAM10 shows a disintegrin domain with a cysteine-rich region, a transmembrane region and finally a cytoplasmic domain (Fig. 2). The cytoplasmic tail of ADAM10 contains a RRR sequence responsible for the retention of ADAM10 in the ER. The mechanism by which this sequence is masked to allow the traffic of ADAM10 to the plasma membrane is unknown [31]. The targeting of ADAM10 to the glutamatergic synapse requires the interaction of its intracellular proline rich domain with the SH3 domain of SAP97 [32-35]. (Fig. 2). The relevance of ADAM10 in APP processing and $\mathrm{AD}$ is documented in numerous papers. We know for instance that overexpression of ADAM10 is able to increase $\alpha$-cleavage, while the opposite effect, a reduction of the non-amyloidogenic pathway activity, is seen with negative form of ADAM10 or ADAM10 RNAi [11, 12, 14]. Furthermore, Jorissen and colleagues recently showed that 
sAPP $\alpha$ secretion is almost abolished in ADAM10 KO mice [36]. The ADAM10 intracellular trafficking, a key point in regulating the non-amyloidogenic pathway, can furthermore be regulated by muscarinic receptors [37]. Some acetylcholinesterase inhibitors have been found also able to modulate the trafficking of ADAM10/17 and APP [38]. These drugs have already been proposed for reversing the cognitive deficits in $\mathrm{AD}$ patients by potentiating the effect of acetylcholine. Furthermore, it seems that they could also act at the same time by stimulating the non-amyloidogenic pathway. The attempts of stimulating the non toxic processing of APP started years ago, in fact already in the 90s, some groups demonstrated how activation of PKC stimulates $\alpha$-cleavage of APP [39] at the cell surface [40] or competing with BACE1 in the TGN [21]. More recently, new PKC activators directly increasing $\alpha$-secretase activity, have been designed and tested [41]. Furthermore, 5-HT4 receptors have been found to regulate $\alpha-$ secretase activity [42-44]. Stimulation of these receptors has in fact induced an increased production of sAPP $\alpha$ both in cell lines and in vivo [45], a well-promising observation that needs further elucidations regarding the pathways involved. Cholesterol has also been suggested to have a role as a modulator of $\alpha$-secretase activity [46, 47]. A huge body of evidence is linking cholesterol, and lipids in general, to $\mathrm{AD}$, although their relation and mechanism of action are not completely clear. Indeed, it has been shown that cholesterollowering drugs, like statins, upregulate $\alpha$-secretase activity [48]. In addition, Kojro's group demonstrated, targeting ADAM10 to lipid rafts domains, that ADAM10 is unable to cleave APP in a cholesterol-rich environment. Finally, the activity of ADAM10 can also be increased at the transcriptional level. In this regard overexpression of SIRT-1, a NAD-dependant deacetylase, reduce the formation of plaques in brain of mice overexpressing APP/PSEN1 [49]. Retinoic acid, a metabolite of Vitamin A increases ADAM10 expression via the RAR $\beta$ receptor in a SIRT1 dependent manner [50-52]. Retinoic Acid Receptor $\alpha$ (RAR $\alpha)$ agonists are also neuroprotective and able to inhibit both extracellular and intracellular A $\beta$ production. Concluding, different strategies aimed at stimulating the non-amyloidogenic pathway can be proposed at the transcriptional level, at the level of ADAM10 trafficking to the plasma membrane or directly by stimulating the alpha-secretase activity with GPCRs for example. Saftig and Reiss in 2011 published an interesting review on ADAM functions and pointed out the variety of roles that they cover, including beneficial effects on the homeostasis of the nervous system, a proinflammatory role in vascular diseases and a stimulatory effect on cell migration and metastasis [53]. If a treatment completely void of collateral effects remains yet an utopia the field is certainly promising.

\section{4. $\beta$-Secretase and the amyloidogenic pathway}

Interestingly, while $\alpha$-secretase cleavage of APP is highly active in non neuronal cells, in neurons the amyloidogenic pathway is predominant, an observation that could be explained by the high levels of $\beta$-secretase in this type of cells $[54,55]$, reviewed by [56]. $\beta$-Secretase has been identified as the enzyme BACE1 [57-59], although a minor activity has been attributed also to BACE2 [60]. While BACE1 in fact is highly expressed in the brain where it interacts with APP, BACE2 is poorly present [19]. In favour of the theory identifying BACE1 as the $\beta$-secretase, it has been demonstrated that its inhibition lowers the levels of $A \beta$ in the brain [61]. BACE1 is a transmembrane aspartic protease of 501 residues encoded by a gene on chromosome $11[58,59]$ (Fig. 2). It cleaves APP mainly at the N-terminal side of Asp1 of the $A \beta$ sequence, although other cleavage sites exist, like the one at Glu11. The cleavage at Asp1 produces a $\mathrm{N}$-terminal truncated APP, named sAPP $\beta$, and a C-terminal membraneassociated fragment, $\mathrm{C} 99$ (or $\mathrm{CTF} \beta$ ). The BACE1 homodimer is 30 times more active than 
the monomer [62], reviewed by [63]. While the palmitoylation of residues 478, 482 and 485, seems to be essential for the homodimerization, Parsons's group also demonstrated that a correct trafficking of BACE, requires both palmitoylation and the association with a farnesylated $53 \mathrm{kDa}$ protein [64] (Fig. 2). BACE activity is influenced by the $\mathrm{pH}$, being the most favourable environment an acidic pH (about 5), like the one in endosomes [65]. Indeed, FRET analyses show that $\beta$-secretase interacts with APP mainly in endosomes in native conditions [66]. BACE trafficking into endosomes and lysosomes is regulated by the LL (dileucine) motif [67], while its sorting and recycling to the TGN and to the cell surface is regulated by GGA protein (Golgi-localized, Gamma Adaptin ear-containing, ARF-binding protein family), in particular GGA1 [68, 69] and, negatively, by GGA3 [70-72] (Fig. 2). Furthermore, it has been demonstrated that small GTPase ADP Ribosylation Factor 6 (ARF6) modulates BACE trafficking [73] (Table 1). Other actors like reticulon/NOGO proteins interact with BACE but it's not clearly elucidated if their action is on the trafficking or on the activity of the enzyme, reviewed by [74] (Fig. 2). In a recent paper, Obregon and colleagues showed that sAPP $\alpha$ modulate A $\beta$ production directly acting on BACE [75]. BACE1 acts in fact primarily in endosomes, but its action has been revealed also in lysosomes and at the cell membrane in lipid rafts. Multiple lines of evidence suggest an interaction between APP and $\beta$ secretase in these small (10-200 nm), heterogeneous, highly dynamic, sterol- and sphingolipid-enriched domains that compartmentalize cellular processes [76], thus enabling the formation of $\mathrm{A} \beta$ and increasing the probability of $\mathrm{AD}$ [77]. In a recent review, Vetrivel and Thinakaran, estimate that only $10 \%$ of the APP arrives to the plasma membrane in a constitutive manner [78] APP resides only briefly at the cell-surface where it can undergo $\alpha$ cleavage or is internalized into endosomes $[79,80]$. In this regard the "retromers" acquire importance, a family of proteins that mediate the retrieval of transmembrane proteins from the endosomes to the trans-Golgi network. Misregulation of retromers or retromer-associated proteins influences endosomal localization of APP/BACE1 and so the formation of A $\beta$ [81]. It has recently been shown how sortilin, a Vps domain-sorting receptor, can modulate this retromer-mediated trafficking of BACE1 [82] (Fig. 2). In addition, adaptor proteins can have a role in this process. These proteins are in fact known for their capability of affixing cargos to the retromers. SorLA for instance, a member of the low lipoprotein receptor superfamily [83], binds APP and function as an adaptor protein linking it to retromers. Promoting the transport of APP to the Golgi they have a fundamental role in keeping APP away from the endosomes and limiting $A \beta$ production. Interestingly, Scherzer and colleagues in 2004 reported that in $A D$ patients there is a reduction of SorLA levels [84]. Note however that a recent heterodox report suggests an important production of $A \beta$ in the Golgi complex due a high concentration of APP, BACE1 and $\gamma$-secretase [85] Finally, it has been recently demonstrated that $A \beta$ can mediate its own production through a feedback mechanism on APP and BACE1 acting as a transcription factor [86] (Fig. 2). To note that regulators of BACE expression levels have been identified also in some AD risk factors like hypoxia and oxidative stress, together with traumatic brain injury and infection of neuronal cells with herpes simplex virus [74].

\section{5. $\gamma$-Secretase}

Following the first APP cleavage by $\alpha$ - or $\beta$-secretases, the $\gamma$-secretase complex cleaves the C-terminal fragments, C83 and C99, an activity present both at cell surface and in endosomes [87], in what is called "Regulated Intramembrane Proteolysis" (RIP) (reviewed in [23]). The $\gamma$-secretase complex is composed of Nicastrin (Nct), Anterior PHarynx defective one (APH1), 
Presenilin ENhancer 2 (PEN2), and Presenilin 1 (PSEN1) and/or 2 (PSEN2) [88, 89][90] (Fig. 2). In the $\gamma$-secretase, every element seems to participate in a stoichiometry ratio 1:1:1:1 [91, 92]. The cleavage of $\mathrm{C} 83$ and $\mathrm{C} 99$ brings to the formation of $\mathrm{p} 3$ and $\mathrm{A} \beta$ respectively (mainly 40 and 42), together with an APP intracellular domain (AICD), whose length can vary from 57 to 59 residues. In this complex, the active site is represented by the presenilins, while nicastrin is responsible for the anchoring of the substrate [93-95], PEN-2 probably stabilizes presenilin in the complex and still not elucidated is the role of APH-1. Mutations at the level of the presenilins are accountable for the majority of familial AD cases (reviewed by [96]). Indeed, inhibition of the two presenilins completely abolishes the formation of $A \beta[97,98]$. The activity of the $\gamma$-secretase can be modulated by interaction with partners. Up to 40 proteins have been identified as possible $\gamma$-secretase ligands but their actions are poorly understood (reviewed by [16]). Recently, Michaki and colleagues showed that downregulating Abca2, an AT-binding cassette transporter alters nicastrin maturation and consequently reduce A $\beta$ production [99] (Fig. 2) (Table 1). Other demonstrated regulations are assumed by Rer1, which negatively modulates the $\gamma$-secretase complex assembly [100, 101] and the orphan G-protein coupled receptor 3 [102], which increases the cell-surface localization of the mature complex. Directly acting on the enzyme activity are instead $\beta_{2-}$ adrenergic receptors [103], but also CD 147 antigen (basigin) [104] and 21-KD (TMP-21) [105] (revised by [106]) (Fig. 2). Furthermore, Hoshino and colleagues demonstrated that prostaglandin E2, a mediator of inflammation, is able to increase $\gamma$-secretase activity and $A \beta$ production through an EP(4)-mediated internalization of PS1 [107]. $\gamma$-secretase activity is shown to be dependent also on Arc, a postsynaptic protein that regulates the trafficking to endosomes and associates with PS1. The genetic deletion of Arc is in fact able to reduce A $\beta$ production and is therefore fundamental in the developing of AD [108]. A group of drugs, GSMs $(\gamma$-secretase modulators) that include non-steroidal anti-inflammatory drugs, are able to modify the ratio between $A \beta_{38}$ and $A \beta_{42}$ production [109]. A novel $\gamma$-secretase activating protein (GSAP) drastically and selectively increases $A \beta$ production through a mechanism involving its interactions with both $\gamma$-secretase and its substrate, the amyloid precursor protein carboxy-terminal fragment (APP-CTF). Interestingly GSAP does not interact with Notch, nor does it affect its cleavage [110]. Concerning instead the regulation at the transcriptional level, Wexler and colleagues recently found an implication of Wnt-1 in the modulation of PSN-1 levels (Wexler et al 2011), while Dunys pointed out the role of p53 in the regulation of Pen2 transcription [111].

\section{APP trafficking}

APP roadmaps in the cell are numerous. We will try to summarize the main consensus that emerge showing the main APP associated proteins that have been involved to regulate this trafficking and the consequences related to APP processing.

\subsection{From ER to Golgi}

APP in biosynthesised in ER and transported to the Golgi via the constitutive secretory pathway. A very recent report, dealing with comparison of APP695 and APP751 homodimerization, demonstrated that APP was highly detected in ERGIC, the intermediate compartment between ER and Golgi [112] (Fig. 3). Both APP isoforms are able to forms homodimers that are generated along the secretory pathway in COS-7, CHO and MEF APP $\%$ cells. However, the KPI domain present in the extracellular part of APP751 enhances this dimerization, appears to promote a more efficient sorting of APP751 to the plasma membrane 
and consequently to favour its non-amyloidogenic processing. Conversely, KPI mutants are retained in the ER and KPI-devoid APP695 (a form specifically expressed in neurons) is less efficiently driven to the plasma membrane, thus leading to more A $\beta$ production than APP751 form [112]. In conclusion, native folding of APP and homodimerization impact it sorting of ER and processing along amyloidogenic or non-amyloidogenic pathways.

\subsection{From Golgi, TGN to plasma membrane}

In the Golgi apparatus, APP undergoes various post-translational modifications (N- and Oglycosylations, phosphorylations and tyrosine sulfations). Within the Golgi network, APP can meet the $\alpha$-secretase ADAM10 (Fig. 3), which gets its mature form in late TGN segments [25] and process APP at the $\alpha$-site. However, this is representing a minor part of the $\alpha$ secretase activity found at the plasma membrane [21-23]. Curiously only few data are available on the regulation of the traffic of APP from the Golgi to the plasma membrane where its cleavage by $\alpha$-secretase is mainly occurring. $\beta$-Secretase activity is also present in the Golgi, even if a broad range of studies tends do consider than the major site of $\beta$-secretase action is in the endosomal compartments. A clear consensus is that favouring TGN exit and transport to plasma membrane insertion enhances the non-amyloidogenic pathway. Calsyntenin-1 is involved in kinesin-1-dependent TGN exit of APP [113] and has recently been shown to be co-transported with APP along axons [114]. The loss of calsyntenin-1 impairs APP axonal transport resulting in increased A $\beta$ production. Moreover, a reduction in calsyntenin-1 expression in AD patient brains is correlated to an increase in A $\beta$ burden [114]. Rab GTPases role is well established in protein sorting and it has been demonstrated that Rab3A GTPase activity is required for APP anterograde transport [115]. Interestingly, this work demonstrated also that APP can be cleaved by ADAM10 in transport vesicles. Even if only low amount of $\mathrm{sAPP} \alpha$ are produced in vesicles on the way to the plasma membrane, such an observation add to the evidence that impaired APP transport along the constitutive secretary pathway can be deleterious and lead to increased $A \beta$ production.

\subsection{From plasma membrane to early endosomes}

The endocytic sorting of APP is far more documented than its travel trough the constitutive secretory pathway. Indeed, A $\beta$ production is clearly linked to APP endocytosis in endosomal compartment where $\beta$ - and $\gamma$-secretase seems to exert their major action $[116,117]$. Rapidly after its insertion at the plasma membrane, APP undergoes a clathrin-mediated endocytosis [118] (Fig. 3). Interestingly, BACE1 is following a different route, controlled by ARF6 (ADP Ribosylation factor 6), to meet APP in Rab GTPase 5-positive early endosomes [73]. The YENPTY motif in the C-terminal domain of APP is crucial for its internalization [119]. Indeed, many intracellular adaptors bind to this region such as Fe65, Mint proteins, Dab1 or JIP (c-Jun N-terminal kinase-interacting proteins) family (Fig. 4).

Fe65 couples APP to several Low-Density Lipoprotein receptors (LDL-Rs) found to regulate the clathrin-dependent internalization of APP (reviewed in [120]. The low-density lipoprotein receptor-related protein 1 (LRP1)-Fe65-APP complex is rapidly internalized, thus decreasing the release of $\operatorname{sAPP} \alpha$ and increasing $A \beta$ production [121]. Moreover LRP1 is also able to interact directly with APP or to bind $\mathrm{A} \beta$ and to contribute to its clearance $[120,122,123]$ Apolipoprotein E receptor 2 (ApoER2) is another protein able to interact directly with APP, extracellularly via the cell adhesion protein linker F-spondin [124] or intracellularly via Dab1 (Disabled family member) [125], Mint1 [126] or Fe65 adaptors [124] (Fig. 4). Depending of the linker protein involved and whether ApoER2 and APP are connected intracellularly or extracellularly, internalization and traffic-dependent APP processing can be modulated towards either amyloidogenic or non-amyloidogenic pathways [120]. A newly identified 
LDL-receptor, LRAD3 (LDL Receptor class A Domain containing 3) has been also shown to bind APP C-terminal domain and to co-localise with APP in intracellular compartments. LRAD3 expression increases $A \beta$ generation, further raising the importance of LDL-Rs in APP metabolism [127]. Moreover, Fe65 has just been described linking APP and VLDL receptor, thus modifying their trafficking and processing [128].

Mints proteins (also named X11s or APP binding family A) include Mint1/X11/X11 $\alpha$ and Mint2/X11L/X11 $\beta$ that are neuron specifically expressed and the ubiquitous Mint3/X11L2/X11 $\gamma[129,130]$. They all interact via their PTB domain with the YENPTY motif of APP (Fig. 4) and suppression of each individual Mint protein slow-down the appearance of plaques in AD mouse models [131]. However deciphering their precise positive or negative role in $A \beta$ generation is difficult as overexpression of Mint1, Mint 2 or Fe65 also induce a decrease in $\mathrm{A} \beta$ burden in AD transgenic mice (reviewed in [132]). As Fe65, Mints are cytosolic adaptors that bind and connect multiple actors in APP processing. Recently, the activation mechanism of these proteins has been resolved. Matos et al; have just demonstrated that Mint1 undergoes a conformational switch between a "closed" state unable to bind to APP and an "open" state able to interact with APP [133]. Interestingly, this conformational change of Mint1 could induce conformational change in APP that would be related to the modifications of its processing. Thus, the Mint adaptor proteins would not be simple "connectors" of AD related proteins, but could have a more "active" effect.

Adding to the general consensus that APP endocytosis increases A $\beta$ generation, Watanabe et al. recently demonstrated that overexpression of FBL2 (F-box and Leucine rich repeat protein 2), a component of the E3 ubiquitin ligase complex, inhibits APP endocytosis by promoting its ubiquitination [134] (Fig. 3). APP ubiquitination has a double effect, i) ubiquitination of cell surface APP reduces the amount of APP in endosomal compartment and leads to a lowering of $A \beta$ production and ii) ubiquitination of intracellular APP promotes its degradation by the proteasome.

APP endocytosis can be accelerated by an increase in clathrin-coated vesicles dynamic following some GPCR endocytosis for example $\beta_{2}$-adrenergic receptors [103].

Since the identification of PICALM (phosphatidylinositol-binding clathrin assembly protein) as a novel genetic risk factor for AD in genome-wide association studies [135-137], APP endocytosis mechanisms are more than ever studied in view of therapeutic solutions for AD.

\subsection{From early endosome to late endosomes and lysosomes}

$\gamma$-secretase proteins and activity have been detected in the late endosomal compartments and lysosomes that are also sites of $A \beta$ production (reviewed in $[16,138]$ ). Recently, a direct transport of APP from the plasma membrane to the lysosomes has been suggested [139]. Part of the wild type APP seems to be transported directly to the lysosomal compartment where it is degraded, while APP bearing Swedish or London mutation would pass trough classic clathrin endocytosis and endosomal route to reach lysosomes.

\subsection{From endosomes back to the Golgi}

Sortilin-related receptor (SorLA/LR11), neuronal apolipoprotein E receptors interact with APP by undefined domains and its expression induces a relocation of cell surface APP and endosomes to the TGN, thus decreasing sAPP $\alpha$ and A $\beta$ generation [83]. SorLA levels are significantly reduced in lumbar samples and in ventricular cerebrospinal fluid of AD patients [140] and SORL1/SorLA mutations have been identified in autosomal dominant early-onset $\mathrm{AD}$ [141]. A recent study demonstrated that the retromer complex bind to the FANSHY sequence in the cytoplasmic domain of SorLA and transport APP from the endosomal compartment to the Golgi/TGN [142] (Fig. 3). The retromer is a protein complex composed 
of 8 proteins (sorting nexins (SNX) SNX1, SNX 2, SNX 5 and SNX 6, vacuolar protein sorting (VPS) VPS26A, VPS26B, VPS29 and VPS35) that mediates the transport from endosomes to the Golgi [143, 144]. Retromer deficiency has been reported in late-onset AD [145]. APP does not bind to the VPS35 subunit of the retromer, the one in charge of cargobinding. However, due to the association of SorLA with the retromer, APP can be transported from the endosomes to the Golgi, thus leading to a reduction in A $\beta$ production [142].

To complete the APP trafficking description, it is important to note the traffic of APP from endosomes back the plasma membrane due to its interaction with SNX17 [146].

\subsection{From Golgi directly to the endosomes}

This route is classically described to be followed by BACE1 via the action of GGA1 and GGA3 proteins [68, 147, 148] (Fig. 3). However, the classical view that APP, $\beta$ - and $\gamma$ secretases are all together present in early endosomes to produce the highest amount of A $\beta$ has been challenged by Burgos et al. proposing that high concentrations of APP, $\beta$ - and $\gamma$ secretases are present in the Golgi to produce $A \beta$ [85]. Thus, a way of diverting this $A \beta$ production in the Golgi is via the export of APP from the TGN to endosomes by the interaction of its YKFFE intracellular sequence with the AP-4 complex.

\section{GPCR regulation of APP processing}

Some neurotransmitter systems, such as cholinergic, serotonergic, glutamatergic or adrenergic systems, are widely disturbed in $\mathrm{AD}$ and are involved in the associated symptoms. However, many neurotransmitters GPCRs have been demonstrated to modulate directly or indirectly the production of $A \beta$. Thus, GPCRs give rise to novel interest in order to reduce physiopathological mechanisms of AD. GPCRs can regulate APP metabolism by modulating $\alpha-, \beta$ - and $\gamma$-secretase activities, APP trafficking and A $\beta$ peptides stability [149]. Conversely, disequilibrium of APP processing towards the amyloidogenic pathway could affect GPCRs functions. Indeed, $A \beta$ peptides oligomerization induces an abnormal clustering of metabotropic glutamate receptors (mGluR5) in synapses [150]. Such mGluR5 accumulation contributes to synaptotoxicity.

Amyloid beta peptide-(1-42) also induces internalization and degradation of $b_{2}$-adrenergic receptors $\left(\beta_{2}-A R\right)$ in neurons [151]. Indeed $A \beta$ binds to many others targets such as APP itself (inducing homodimerization), the $75-\mathrm{kD}$ neurotrophin receptors inducing apoptosis and prion protein (PrP) affecting synaptic plasticity [152].

Many GPCRs stimulate $\alpha$-secretase activity [149] via pleiotropic signalling pathways not always clearly defined, such as cyclic AMP (cAMP)/protein kinase A (PKA), phosphatidylinositol 3-kinase (PI3K), mitogen-activated protein kinase/extracellular signalregulated kinases (MAPK/ERK) and protein kinase C (PKC) pathways. The precise targets of those pathways are not known.

Among GPCRs positively coupled to $\mathrm{G}_{\mathrm{s}}$ protein that has been involved in the regulation of APP processing, we can quote here the serotonin type 4 receptor $\left(5-\mathrm{HT}_{4} \mathrm{R}\right)$. $5-\mathrm{HT}_{4} \mathrm{R}$ stimulation activates PKA and increases intracellular cAMP production. Robert and colleagues demonstrated that agonist-activation of the receptor promotes SAPP $\alpha$ release and reduces $A \beta$ peptides production by increasing $\alpha$-secretase activity [42, 153, 154] (Fig. 5). This effect is cAMP-dependent but PKA-independent and involves Epac, via the activation of Rap1 and Rac, a small GTPase of the Rho family [155]. In addition to its beneficial role on APP metabolism, 5- $\mathrm{HT}_{4} \mathrm{R}$ via its cAMP production, Src activation and $\mathrm{K}^{+}$channel regulation might also have an interest in correcting neuronal deficits by promoting neurite outgrowth, neuronal differentiation, acetycholine release and synaptic plasticity [156] [157-161]. 
Belonging also to the $\mathrm{G}_{\mathrm{s}}$-coupled receptors, $\mathrm{PAC}_{1}$ receptor is one of the Pituitary Adenylate Cyclase-Activating Polypeptide (PACAP) receptor subtypes, which is the most expressed in the central nervous system [162]. $\mathrm{PAC}_{1} \mathrm{R}$ activation promotes APP processing by ADAM10 and thus increases SAPP $\alpha$ release (Fig. 5). This effect is regulated by PI3K and MAPK, including ERK1 and ERK2, pathways. In vivo, PACAP reduces mRNA level of the A $\beta$ peptide transporter receptor and enhances neprilysin expression [163]. Another study showed that ERK can regulate ADAM17. ERK phosphorylates the $\alpha$-secretase, which promotes their interaction and thus ADAM17 activity [164]. Finally, MAPK pathway is involved in the regulation of APP processing by $\mathrm{PKC}$ [165].

$\mathrm{PKC}$ is the key kinase able to regulate APP processing [166, 167]. PKC activation can be controlled by GPCRs stimulation such as muscarinic acetylcholine receptors (mAchRs). Among the five $m A c h R s$ subtypes described, $\mathrm{M}_{1}$ and $\mathrm{M}_{3}$ receptors are known, upon agonist stimulation, to promote $\alpha$-secretase activity and sAPP $\alpha$ release via PKC pathway $[168,169]$. $\mathrm{M}_{1}$ receptor is particularly high expressed in the affected brain areas in $\mathrm{AD}$, like the cortex and the hippocampus, thus, research focuses on this receptor [170]. Activation of $\mathrm{M}_{1}$ receptor, by a series of agonists, mimics PKC effects by increasing sAPP $\alpha$ release and by decreasing $\mathrm{A} \beta$ peptides production [171] (Fig. 5). This effect is $\mathrm{PKC} \alpha$ and $\mathrm{PKC} \varepsilon$-dependent and is controlled neither by MAPK/ERK1 pathway nor by ADAM17, contrary to the regulation of the protein prion cleavage [37]. Conversely, genetic ablation of $\mathrm{M}_{1}$ receptor expression $\left(\mathrm{M}_{1}{ }^{-1} /\right)^{-}$ in the $\mathrm{APP}_{\text {Swe/Ind }}$ mice (AD mouse model expressing a transgenic APP bearing the Swedish and Indiana human mutations) showed that the absence of $\mathrm{M}_{1}$ receptor promotes the amyloidogenic pathway. Indeed, an increase in $A \beta$ peptides production and amyloid plaques in the brain and a decrease of sAPP $\alpha$ fragments release was observed in the $\mathrm{M}_{1} \%$-APP $\mathrm{P}_{\text {swe/ind }}$ mice [172]. Another group recently reproduced the results of this study by crossing $\mathrm{M}_{1} \%$ mice with two additional AD mouse models (3xTgAD and Tg-SwDI) [173]. Development of efficient compounds targeting M1 mAChR was difficult due to the lack of specific molecules. Indeed, a global activation of mAChRs by carbachol does not affect importantly sAPP $\alpha$ release, which indicates that other $\mathrm{mAChR}$ subtypes, likely $\mathrm{M}_{2}$ receptors, decrease protective fragments liberation [174]. Based on these results, several $M_{1}$ receptor agonists have been developed: (i) AF102B which leads to a decrease of $\mathrm{A} \beta$ peptides in the cerebrospinal fluid, (ii) AF276B which improves amyloid pathology by decreasing amyloid plaques number in the cortex and the hippocampus via ERK1/ERK2 modification and increase of ADAM17 expression and stability and (iii) more recently TBPB, an allosteric specific M1 positive regulator, potentiates M1-induced regulation of NMDA receptor currents in hippocampal neurons, increases the non-amyloidogenic pathway and decrease $A \beta$ production [175-177].

In a lesser extent, calcium could also be implicated in the APP metabolism regulation by GPCRs. A G protein-coupled nucleotide receptor, $\mathrm{P}_{2} \mathrm{Y}_{2}\left(\mathrm{P} 2 \mathrm{Y}_{2} \mathrm{R}\right)$, is able to upregulate sAPP $\alpha$ release [178] (Fig. 5). This mechanism is extracellular calcium-dependent, but surprinsingly intracellular calcium-independent. The MAP-Kinase pathway seems likewise to be implicated, at least in part, because its inhibition does not completely abolish the liberation of neuroprotective fragments.

Beyond the regulation of APP processing via intracellular pathways, GPCRs can also subtly modulate the trafficking of amyloid cascade players. This mechanism of regulation is a multilevel system because GPCRs trafficking is also highly controlled. Indeed, some studies demonstrated that GPCRs can be internalized via clathrin coated pits into endosomes together with $\beta$ - and $\gamma$-secretases. Among the GPCRs described to modulate secretases via a direct interaction, the $\beta_{2}$-adrenergic receptor $\left(\beta_{2}-\mathrm{AR}\right)$ and the $\delta$-opioid receptor (DOR) have been reported [103] (Fig. 5). The activation of these two GPCRs promotes $\gamma$-secretase activity and then $\mathrm{A} \beta$ peptides accumulation in vitro, independently of cAMP. Furthermore, $\beta_{2}$-AR agonist treatment increases plaques formation in vivo [103]. Conversely, an antagonist treatment 
abolishes $A \beta$ peptides production. The enhancement of $\gamma$-secretase activity by $\beta_{2}$-AR and DOR requires a direct interaction between these receptors and the presenilin 1 (PS1), one of the catalytic components of the $\gamma$-secretase complex [103]. Conversely, during the AD pathogenesis, the toxic $A \beta$ peptides can bind a phosphorylated form of $\beta_{2}-A R$, which leads to a slow internalization and then to the degradation of the GPCR [151]. Another study demonstrated that BACE1 belongs to the DOR $/ \gamma$-secretase complex [179]. DOR endocytosis, after activation, leads to a co-endocytosis of BACE1 and the $\gamma$-secretase complex. Thus, the secretases are transported from the cell surface to the late endosomes, an effect that promotes a specific APP proteolysis towards amyloidogenic pathway. An antagonist treatment or the invalidation of DOR decrease the $\beta$ - and $\gamma$-secretase activities and improve AD pathology in a mouse model.

Besides, expression of G Protein-Coupled Receptor 3 (GPR3), a constitutively active orphan receptor, is able by itself to modulate $A \beta$ peptides generation, independently of the cAMP pathway [180] (Fig. 5). GPR3 overexpression promotes $A \beta_{1-40}$ and $A \beta_{1-42}$ peptides release in hippocampal neurons, whereas GPR3 invalidation prevents formation of the toxic peptides in vitro and in AD mouse models. GPR3 enhances complex assembly of the $\gamma$-secretase and modulates $\gamma$-secretase activity by promoting its localization and trafficking at the plasma membrane in special membrane areas called "detergent-resistant membranes" [180].

GPCRs are not only able to regulate secretases activities but also to control their cellular localization and APP trafficking [102, 149, 179]. Controlling in the same time the targetting of APP and the desired secretase upon GPCR activation or expression is of particular insterest to conceive new therapeutical strategies that could avoid adverse side-effects.

\section{Conclusion}

With the present review we aimed at giving a comprehensive picture of APP processing, putting in light the variety of factors involved and the multiplicity of points where a pharmacological action could take place. From the initial identification of the processing event in the two ways, amyloidogenic and non-amyloidogenic, enormous steps have been done towards a more profound understanding. Research has developed in different fields and it is from the sharing of all the specific notions acquired that unrevealing the complexity of APP processing is becoming possible. Our current knowledge derives from extensive genetic screenings, together with detailed biochemistry investigations and the most updated behavioural science. Of vital importance, the numerous studies performed in cell cultures, in neurons like in other type of cells, accompanied by validation with animal models and in vivo treatments. All these techniques put together suggested the importance of compartmentalization and underlined the huge number of partners that can modulate APP processing. Also, it clearly emerges that the biggest problem in planning a strategy against $\mathrm{AD}$, is the complex and multiple functions of putative targets. In this regard, the development of pharmaceutical compounds able to modulate at the same time, maybe with a synergic effect, more than a single target, is becoming an appealing field. Ideally, lower doses of the drugs will be necessary to exert the desired effect reducing in this way, if not completely abolishing, collateral effects. 


\section{Acknowledgments}

The authors are supported by grants from CNRS, INSERM, the French Minister of Research (ANR Blanc 2006, to AD and SC), the France Alzheimer association (to SC), the Soroptimist International (French Union, to SC) and the Languedoc Roussillon region ("Chercheuse d'Avenir 2012", to SC).

\section{References}

[1] Alzheimer A, Stelzmann RA, Schnitzlein HN, Murtagh FR, Clin Anat. 1995;8:429-431.

[2] Glenner GG, Wong CW, Biochem Biophys Res Commun. 1984;120:885-890.

[3] Kang J, Lemaire HG, Unterbeck A, Salbaum JM, Masters CL, Grzeschik KH, Multhaup G, Beyreuther K, Muller-Hill B, Nature. 1987;325:733-736.

[4] St George-Hyslop PH, Neurobiol Aging. 1998;19:133-137.

[5] Markesbery WR, Lovell MA, Neurobiol Aging. 1998;19:33-36.

[6] Castellano JM, Kim J, Stewart FR, Jiang H, DeMattos RB, Patterson BW, Fagan AM, Morris JC, Mawuenyega KG, Cruchaga C, Goate AM, Bales KR, Paul SM, Bateman RJ, Holtzman DM, Sci Transl Med. 2011;3:89ra57.

[7] Deane R, Sagare A, Hamm K, Parisi M, Lane S, Finn MB, Holtzman DM, Zlokovic BV, J Clin Invest. 2008;118:4002-4013.

[8] Zetzsche T, Rujescu D, Hardy J, Hampel H, Expert Rev Mol Diagn. 2010;10:667-690.

[9] Fahrenholz F, Gilbert S, Kojro E, Lammich S, Postina R, Ann N Y Acad Sci. 2000;920:215-222.

[10] Asai M, Hattori C, Szabo B, Sasagawa N, Maruyama K, Tanuma S, Ishiura S, Biochem Biophys Res Commun. 2003;301:231-235.

[11] Kuhn PH, Wang H, Dislich B, Colombo A, Zeitschel U, Ellwart JW, Kremmer E, Rossner S, Lichtenthaler SF, Embo J. 2010;29:3020-3032.

[12] Lammich S, Kojro E, Postina R, Gilbert S, Pfeiffer R, Jasionowski M, Haass C, Fahrenholz F, Proc Natl Acad Sci U S A. 1999;96:3922-3927.

[13] Buxbaum JD, Liu KN, Luo Y, Slack JL, Stocking KL, Peschon JJ, Johnson RS, Castner BJ, Cerretti DP, Black RA, J Biol Chem. 1998;273:27765-27767.

[14] Lopez-Perez E, Zhang Y, Frank SJ, Creemers J, Seidah N, Checler F, J Neurochem. 2001;76:1532-1539.

[15] Slack BE, Ma LK, Seah CC, Biochem J. 2001;357:787-794.

[16] Sannerud R, Annaert W, Semin Cell Dev Biol. 2009;20:183-190.

[17] Weskamp G, Kratzschmar J, Reid MS, Blobel CP, J Cell Biol. 1996;132:717-726.

[18] Black RA, Rauch CT, Kozlosky CJ, Peschon JJ, Slack JL, Wolfson MF, Castner BJ, Stocking KL, Reddy P, Srinivasan S, Nelson N, Boiani N, Schooley KA, Gerhart M, Davis R, Fitzner JN, Johnson RS, Paxton RJ, March CJ, Cerretti DP, Nature. 1997;385:729-733.

[19] Marcinkiewicz M, Seidah NG, J Neurochem. 2000;75:2133-2143.

[20] Parvathy S, Hussain I, Karran EH, Turner AJ, Hooper NM, Biochemistry. 1999;38:97289734.

[21] Skovronsky DM, Moore DB, Milla ME, Doms RW, Lee VM, J Biol Chem. 2000;275:2568-2575.

[22] Huovila AP, Turner AJ, Pelto-Huikko M, Karkkainen I, Ortiz RM, Trends Biochem Sci. 2005;30:413-422.

[23] Lichtenthaler SF, J Neurochem. 2011;116:10-21.

[24] Reiss K, Saftig P, Semin Cell Dev Biol. 2009;20:126-137. 
[25] Moss ML, Bomar M, Liu Q, Sage H, Dempsey P, Lenhart PM, Gillispie PA, Stoeck A, Wildeboer D, Bartsch JW, Palmisano R, Zhou P, J Biol Chem. 2007;282:35712-35721.

[26] Hwang EM, Kim SK, Sohn JH, Lee JY, Kim Y, Kim YS, Mook-Jung I, Biochem Biophys Res Commun. 2006;349:654-659.

[27] Nunan J, Small DH, FEBS Lett. 2000;483:6-10.

[28] Anders A, Gilbert S, Garten W, Postina R, Fahrenholz F, FASEB J. 2001;15:1837-1839.

[29] Roghani M, Becherer JD, Moss ML, Atherton RE, Erdjument-Bromage H, Arribas J, Blackburn RK, Weskamp G, Tempst P, Blobel CP, J Biol Chem. 1999;274:3531-3540.

[30] Kim M, Suh J, Romano D, Truong MH, Mullin K, Hooli B, Norton D, Tesco G, Elliott K, Wagner SL, Moir RD, Becker KD, Tanzi RE, Hum Mol Genet. 2009;18:3987-3996.

[31] Marcello E, Gardoni F, Di Luca M, Perez-Otano I, J Biol Chem. 2010;285:10376-10384. [32] Leonard AS, Davare MA, Horne MC, Garner CC, Hell JW, J Biol Chem. 1998;273:19518-19524.

[33] Sans N, Racca C, Petralia RS, Wang YX, McCallum J, Wenthold RJ, J Neurosci. 2001;21:7506-7516.

[34] Marcello E, Gardoni F, Mauceri D, Romorini S, Jeromin A, Epis R, Borroni B, Cattabeni F, Sala C, Padovani A, Di Luca M, J Neurosci. 2007;27:1682-1691.

[35] Marcello E, Epis R, Saraceno C, Gardoni F, Borroni B, Cattabeni F, Padovani A, Di Luca M, Neurobiol Aging. 2012;33:422 e421-410.

[36] Jorissen E, Prox J, Bernreuther C, Weber S, Schwanbeck R, Serneels L, Snellinx A, Craessaerts K, Thathiah A, Tesseur I, Bartsch U, Weskamp G, Blobel CP, Glatzel M, De Strooper B, Saftig P, J Neurosci. 2010;30:4833-4844.

[37] Cisse M, Braun U, Leitges M, Fisher A, Pages G, Checler F, Vincent B, Mol Cell Neurosci. 2011;47:223-232.

[38] Zimmermann M, Gardoni F, Marcello E, Colciaghi F, Borroni B, Padovani A, Cattabeni F, Di Luca M, J Neurochem. 2004;90:1489-1499.

[39] Mills J, Reiner PB, Neuroscience. 1999;94:1333-1338.

[40] Hung AY, Selkoe DJ, EMBO J. 1994;13:534-542.

[41] Yang HQ, Pan J, Ba MW, Sun ZK, Ma GZ, Lu GQ, Xiao Q, Chen SD, Eur J Neurosci. 2007;26:381-391.

[42] Robert S, Maillet M, Morel E, Launay JM, Fischmeister R, Mercken L, Lezoualc'h F, FEBS Lett. 2005;579:1136-1142.

[43] Robert SJ, Lezoualc'h F, Neurodegener Dis. 2008;5:163-165.

[44] Postina R, J Neurochem. 2012;120 Suppl 1:46-54.

[45] Cachard-Chastel M, Lezoualc'h F, Dewachter I, Delomenie C, Croes S, Devijver H, Langlois M, Van Leuven F, Sicsic S, Gardier AM, Br J Pharmacol. 2007;150:883-892.

[46] Allinson TM, Parkin ET, Turner AJ, Hooper NM, J Neurosci Res. 2003;74:342-352.

[47] Kojro E, Gimpl G, Lammich S, Marz W, Fahrenholz F, Proc Natl Acad Sci U S A. 2001;98:5815-5820.

[48] Kojro E, Fuger P, Prinzen C, Kanarek AM, Rat D, Endres K, Fahrenholz F, Postina R, J Alzheimers Dis. 2010;20:1215-1231.

[49] Donmez G, Wang D, Cohen DE, Guarente L, Cell. 2010;142:320-332.

[50] Jarvis CI, Goncalves MB, Clarke E, Dogruel M, Kalindjian SB, Thomas SA, Maden M, Corcoran JP, Eur J Neurosci. 2010;32:1246-1255.

[51] Tippmann F, Hundt J, Schneider A, Endres K, Fahrenholz F, Faseb J. 2009;23:16431654.

[52] Husson M, Enderlin V, Delacourte A, Ghenimi N, Alfos S, Pallet V, Higueret P, Neurobiol Dis. 2006;23:1-10.

[53] Saftig P, Reiss K, Eur J Cell Biol. 2011;90:527-535.

[54] Haass C, Schlossmacher MG, Hung AY, Vigo-Pelfrey C, Mellon A, Ostaszewski BL, 
Lieberburg I, Koo EH, Schenk D, Teplow DB, et al., Nature. 1992;359:322-325.

[55] Seubert P, Oltersdorf T, Lee MG, Barbour R, Blomquist C, Davis DL, Bryant K, Fritz LC, Galasko D, Thal LJ, et al., Nature. 1993;361:260-263.

[56] Cole SL, Vassar R, Mol Neurodegener. 2007;2:22.

[57] Sinha S, Anderson JP, Barbour R, Basi GS, Caccavello R, Davis D, Doan M, Dovey HF, Frigon N, Hong J, Jacobson-Croak K, Jewett N, Keim P, Knops J, Lieberburg I, Power M, Tan H, Tatsuno G, Tung J, Schenk D, Seubert P, Suomensaari SM, Wang S, Walker D, Zhao J, McConlogue L, John V, Nature. 1999;402:537-540.

[58] Vassar R, Bennett BD, Babu-Khan S, Kahn S, Mendiaz EA, Denis P, Teplow DB, Ross S, Amarante P, Loeloff R, Luo Y, Fisher S, Fuller J, Edenson S, Lile J, Jarosinski MA, Biere AL, Curran E, Burgess T, Louis JC, Collins F, Treanor J, Rogers G, Citron M, Science. 1999;286:735-741.

[59] Yan R, Bienkowski MJ, Shuck ME, Miao H, Tory MC, Pauley AM, Brashier JR, Stratman NC, Mathews WR, Buhl AE, Carter DB, Tomasselli AG, Parodi LA, Heinrikson RL, Gurney ME, Nature. 1999;402:533-537.

[60] Farzan M, Schnitzler CE, Vasilieva N, Leung D, Choe H, Proc Natl Acad Sci U S A. 2000;97:9712-9717.

[61] Sankaranarayanan S, Price EA, Wu G, Crouthamel MC, Shi XP, Tugusheva K, Tyler KX, Kahana J, Ellis J, Jin L, Steele T, Stachel S, Coburn C, Simon AJ, J Pharmacol Exp Ther. 2008;324:957-969.

[62] Westmeyer GG, Willem M, Lichtenthaler SF, Lurman G, Multhaup G, AssfalgMachleidt I, Reiss K, Saftig P, Haass C, J Biol Chem. 2004;279:53205-53212.

[63] Parsons RB, Austen BM, Biochem Soc Trans. 2007;35:974-979.

[64] Parsons RB, Subramaniam D, Austen BM, J Neurochem. 2007;102:1276-1291.

[65] Knops J, Suomensaari S, Lee M, McConlogue L, Seubert P, Sinha S, J Biol Chem. 1995;270:2419-2422.

[66] Kinoshita A, Fukumoto H, Shah T, Whelan CM, Irizarry MC, Hyman BT, J Cell Sci. 2003;116:3339-3346.

[67] Koh YH, von Arnim CA, Hyman BT, Tanzi RE, Tesco G, J Biol Chem. 2005;280:32499-32504.

[68] Wahle T, Thal DR, Sastre M, Rentmeister A, Bogdanovic N, Famulok M, Heneka MT, Walter J, J Neurosci. 2006;26:12838-12846.

[69] von Arnim CA, Spoelgen R, Peltan ID, Deng M, Courchesne S, Koker M, Matsui T, Kowa H, Lichtenthaler SF, Irizarry MC, Hyman BT, J Neurosci. 2006;26:9913-9922.

[70] Tesco G, Koh YH, Kang EL, Cameron AN, Das S, Sena-Esteves M, Hiltunen M, Yang SH, Zhong Z, Shen Y, Simpkins JW, Tanzi RE, Neuron. 2007;54:721-737.

[71] Sarajarvi T, Haapasalo A, Viswanathan J, Makinen P, Laitinen M, Soininen H, Hiltunen M, J Biol Chem. 2009;284:34433-34443.

[72] Kang EL, Cameron AN, Piazza F, Walker KR, Tesco G, J Biol Chem. 2010;285:2410824119.

[73] Sannerud R, Declerck I, Peric A, Raemaekers T, Menendez G, Zhou L, Veerle B, Coen K, Munck S, De Strooper B, Schiavo G, Annaert W, Proc Natl Acad Sci U S A. 2011;108:E559-568.

[74] Hunt CE, Turner AJ, FEBS J. 2009;276:1845-1859.

[75] Obregon D, Hou H, Deng J, Giunta B, Tian J, Darlington D, Shahaduzzaman M, Zhu Y, Mori T, Mattson MP, Tan J, Nat Commun. 2012;3:777.

[76] Pike LJ, J Lipid Res. 2006;47:1597-1598.

[77] Ehehalt R, Keller P, Haass C, Thiele C, Simons K, J Cell Biol. 2003;160:113-123.

[78] Vetrivel KS, Thinakaran G, Biochim Biophys Acta. 2010;1801:860-867.

[79] Sisodia SS, Proc Natl Acad Sci U S A. 1992;89:6075-6079. 
[80] Golde TE, Estus S, Younkin LH, Selkoe DJ, Younkin SG, Science. 1992;255:728-730.

[81] Siegenthaler BM, Rajendran L, Neurodegener Dis. 2012;10:116-121.

[82] Finan GM, Okada H, Kim TW, J Biol Chem. 2011;286:12602-12616.

[83] Andersen OM, Reiche J, Schmidt V, Gotthardt M, Spoelgen R, Behlke J, von Arnim CA, Breiderhoff T, Jansen P, Wu X, Bales KR, Cappai R, Masters CL, Gliemann J, Mufson EJ, Hyman BT, Paul SM, Nykjaer A, Willnow TE, Proc Natl Acad Sci U S A. 2005;102:1346113466.

[84] Scherzer CR, Offe K, Gearing M, Rees HD, Fang G, Heilman CJ, Schaller C, Bujo H, Levey AI, Lah JJ, Arch Neurol. 2004;61:1200-1205.

[85] Burgos PV, Mardones GA, Rojas AL, daSilva LL, Prabhu Y, Hurley JH, Bonifacino JS, Dev Cell. 2010;18:425-436.

[86] Bailey JA, Maloney B, Ge YW, Lahiri DK, Gene. 2011;488:13-22.

[87] Fukumori A, Okochi M, Tagami S, Jiang J, Itoh N, Nakayama T, Yanagida K, IshizukaKatsura Y, Morihara T, Kamino K, Tanaka T, Kudo T, Tanii H, Ikuta A, Haass C, Takeda M, Biochemistry. 2006;45:4907-4914.

[88] Shirotani K, Edbauer D, Prokop S, Haass C, Steiner H, J Biol Chem. 2004;279:4134041345.

[89] Wolfe MS, Semin Cell Dev Biol. 2009;20:219-224.

[90] Bergmans BA, De Strooper B, Lancet Neurol. 2010;9:215-226.

[91] Sato T, Diehl TS, Narayanan S, Funamoto S, Ihara Y, De Strooper B, Steiner H, Haass C, Wolfe MS, J Biol Chem. 2007;282:33985-33993.

[92] Renzi F, Zhang X, Rice WJ, Torres-Arancivia C, Gomez-Llorente Y, Diaz R, Ahn K, Yu C, Li YM, Sisodia SS, Ubarretxena-Belandia I, J Biol Chem. 2011;286:21440-21449.

[93] Li YM, Lai MT, Xu M, Huang Q, DiMuzio-Mower J, Sardana MK, Shi XP, Yin KC, Shafer JA, Gardell SJ, Proc Natl Acad Sci U S A. 2000;97:6138-6143.

[94] Shah S, Lee SF, Tabuchi K, Hao YH, Yu C, LaPlant Q, Ball H, Dann CE, 3rd, Sudhof T, Yu G, Cell. 2005;122:435-447.

[95] Wolfe MS, Xia W, Ostaszewski BL, Diehl TS, Kimberly WT, Selkoe DJ, Nature. 1999;398:513-517.

[96] Bertram L, Lill CM, Tanzi RE, Neuron. 2010;68:270-281.

[97] Herreman A, Serneels L, Annaert W, Collen D, Schoonjans L, De Strooper B, Nat Cell Biol. 2000;2:461-462.

[98] Seiffert D, Bradley JD, Rominger CM, Rominger DH, Yang F, Meredith JE, Jr., Wang Q, Roach AH, Thompson LA, Spitz SM, Higaki JN, Prakash SR, Combs AP, Copeland RA, Arneric SP, Hartig PR, Robertson DW, Cordell B, Stern AM, Olson RE, Zaczek R, J Biol Chem. 2000;275:34086-34091.

[99] Michaki V, Guix FX, Vennekens K, Munck S, Dingwall C, Davis JB, Townsend DM, Tew KD, Feiguin F, De Strooper B, Dotti CG, Wahle T, J Biol Chem. 2012;287:1100-1111. [100] Spasic D, Raemaekers T, Dillen K, Declerck I, Baert V, Serneels L, Fullekrug J, Annaert W, J Cell Biol. 2007;176:629-640.

[101] Kaether C, Scheuermann J, Fassler M, Zilow S, Shirotani K, Valkova C, Novak B, Kacmar S, Steiner H, Haass C, EMBO Rep. 2007;8:743-748.

[102] Thathiah A, Spittaels K, Hoffmann M, Staes M, Cohen A, Horre K, Vanbrabant M, Coun F, Baekelandt V, Delacourte A, Fischer DF, Pollet D, De Strooper B, Merchiers P, Science. 2009;323:946-951.

[103] Ni Y, Zhao X, Bao G, Zou L, Teng L, Wang Z, Song M, Xiong J, Bai Y, Pei G, Nat Med. 2006;12:1390-1396.

[104] Zhou S, Zhou H, Walian PJ, Jap BK, Proc Natl Acad Sci U S A. 2005;102:7499-7504.

[105] Chen F, Hasegawa H, Schmitt-Ulms G, Kawarai T, Bohm C, Katayama T, Gu Y, Sanjo N, Glista M, Rogaeva E, Wakutani Y, Pardossi-Piquard R, Ruan X, Tandon A, Checler F, 
Marambaud P, Hansen K, Westaway D, St George-Hyslop P, Fraser P, Nature. 2006;440:1208-1212.

[106] St George-Hyslop P, Fraser PE, J Neurochem. 2012;120 Suppl 1:84-88.

[107] Hoshino T, Namba T, Takehara M, Nakaya T, Sugimoto Y, Araki W, Narumiya S, Suzuki T, Mizushima T, J Biol Chem. 2009;284:18493-18502.

[108] Wu J, Petralia RS, Kurushima H, Patel H, Jung MY, Volk L, Chowdhury S, Shepherd JD, Dehoff M, Li Y, Kuhl D, Huganir RL, Price DL, Scannevin R, Troncoso JC, Wong PC, Worley PF, Cell. 2011;147:615-628.

[109] Czirr E, Cottrell BA, Leuchtenberger S, Kukar T, Ladd TB, Esselmann H, Paul S, Schubenel R, Torpey JW, Pietrzik CU, Golde TE, Wiltfang J, Baumann K, Koo EH, Weggen S, J Biol Chem. 2008;283:17049-17054.

[110] He G, Luo W, Li P, Remmers C, Netzer WJ, Hendrick J, Bettayeb K, Flajolet M, Gorelick F, Wennogle LP, Greengard P, Nature. 2010;467:95-98.

[111] Dunys J, Sevalle J, Giaime E, Pardossi-Piquard R, Vitek MP, Renbaum P, Levy-Lahad E, Zhang YW, Xu H, Checler F, da Costa CA, J Cell Sci. 2009;122:4003-4008.

[112] Ben Khalifa N, Tyteca D, Marinangeli C, Depuydt M, Collet JF, Courtoy PJ, Renauld JC, Constantinescu S, Octave JN, Kienlen-Campard P, FASEB J. 2012;26:855-867.

[113] Ludwig A, Blume J, Diep TM, Yuan J, Mateos JM, Leuthauser K, Steuble M, Streit P, Sonderegger P, Traffic. 2009;10:572-589.

[114] Vagnoni A, Perkinton MS, Gray EH, Francis PT, Noble W, Miller CC, Hum Mol Genet. 2012.

[115] Szodorai A, Kuan YH, Hunzelmann S, Engel U, Sakane A, Sasaki T, Takai Y, Kirsch J, Muller U, Beyreuther K, Brady S, Morfini G, Kins S, J Neurosci. 2009;29:14534-14544.

[116] Grbovic OM, Mathews PM, Jiang Y, Schmidt SD, Dinakar R, Summers-Terio NB, Ceresa BP, Nixon RA, Cataldo AM, J Biol Chem. 2003;278:31261-31268.

[117] Small SA, Gandy S, Neuron. 2006;52:15-31.

[118] Traub LM, Nat Rev Mol Cell Biol. 2009;10:583-596.

[119] Perez RG, Soriano S, Hayes JD, Ostaszewski B, Xia W, Selkoe DJ, Chen X, Stokin GB, Koo EH, J Biol Chem. 1999;274:18851-18856.

[120] Wagner T, Pietrzik CU, Exp Brain Res. 2012;217:377-387.

[121] Pietrzik CU, Yoon IS, Jaeger S, Busse T, Weggen S, Koo EH, J Neurosci. 2004;24:4259-4265.

[122] Ghiso J, Shayo M, Calero M, Ng D, Tomidokoro Y, Gandy S, Rostagno A, Frangione B, J Biol Chem. 2004;279:45897-45908.

[123] Shibata M, Yamada S, Kumar SR, Calero M, Bading J, Frangione B, Holtzman DM, Miller CA, Strickland DK, Ghiso J, Zlokovic BV, J Clin Invest. 2000;106:1489-1499.

[124] Hoe HS, Wessner D, Beffert U, Becker AG, Matsuoka Y, Rebeck GW, Mol Cell Biol. 2005;25:9259-9268.

[125] Howell BW, Lanier LM, Frank R, Gertler FB, Cooper JA, Mol Cell Biol. 1999;19:5179-5188.

[126] He X, Cooley K, Chung CH, Dashti N, Tang J, J Neurosci. 2007;27:4052-4060.

[127] Ranganathan S, Noyes NC, Migliorini M, Winkles JA, Battey FD, Hyman BT, Smith E, Yepes M, Mikhailenko I, Strickland DK, J Neurosci. 2011;31:10836-10846.

[128] Dumanis SB, Chamberlain KA, Sohn YJ, Lee YJ, Guenette SY, Suzuki T, Mathews PM, Pak DT, Rebeck GW, Suh YH, Park HS, Hoe HS, Mol Neurodegener. 2012;7:9.

[129] Okamoto M, Sudhof TC, J Biol Chem. 1997;272:31459-31464.

[130] Okamoto M, Sudhof TC, Eur J Cell Biol. 1998;77:161-165.

[131] Ho A, Liu X, Sudhof TC, J Neurosci. 2008;28:14392-14400.

[132] Miller CC, McLoughlin DM, Lau KF, Tennant ME, Rogelj B, Trends Neurosci. 2006;29:280-285. 
[133] Matos MF, Xu Y, Dulubova I, Otwinowski Z, Richardson JM, Tomchick DR, Rizo J, Ho A, Proc Natl Acad Sci U S A. 2012;109:3802-3807.

[134] Watanabe T, Hikichi Y, Willuweit A, Shintani Y, Horiguchi T, J Neurosci. 2012;32:3352-3365.

[135] Harold D, Abraham R, Hollingworth P, Sims R, Gerrish A, Hamshere ML, Pahwa JS, Moskvina V, Dowzell K, Williams A, Jones N, Thomas C, Stretton A, Morgan AR, Lovestone S, Powell J, Proitsi P, Lupton MK, Brayne C, Rubinsztein DC, Gill M, Lawlor B, Lynch A, Morgan K, Brown KS, Passmore PA, Craig D, McGuinness B, Todd S, Holmes C, Mann D, Smith AD, Love S, Kehoe PG, Hardy J, Mead S, Fox N, Rossor M, Collinge J, Maier W, Jessen F, Schurmann B, van den Bussche H, Heuser I, Kornhuber J, Wiltfang J, Dichgans M, Frolich L, Hampel H, Hull M, Rujescu D, Goate AM, Kauwe JS, Cruchaga C, Nowotny P, Morris JC, Mayo K, Sleegers K, Bettens K, Engelborghs S, De Deyn PP, Van Broeckhoven C, Livingston G, Bass NJ, Gurling H, McQuillin A, Gwilliam R, Deloukas P, Al-Chalabi A, Shaw CE, Tsolaki M, Singleton AB, Guerreiro R, Muhleisen TW, Nothen MM, Moebus S, Jockel KH, Klopp N, Wichmann HE, Carrasquillo MM, Pankratz VS, Younkin SG, Holmans PA, O'Donovan M, Owen MJ, Williams J, Nat Genet. 2009;41:10881093.

[136] Seshadri S, Fitzpatrick AL, Ikram MA, DeStefano AL, Gudnason V, Boada M, Bis JC, Smith AV, Carassquillo MM, Lambert JC, Harold D, Schrijvers EM, Ramirez-Lorca R, Debette S, Longstreth WT, Jr., Janssens AC, Pankratz VS, Dartigues JF, Hollingworth P, Aspelund T, Hernandez I, Beiser A, Kuller LH, Koudstaal PJ, Dickson DW, Tzourio C, Abraham R, Antunez C, Du Y, Rotter JI, Aulchenko YS, Harris TB, Petersen RC, Berr C, Owen MJ, Lopez-Arrieta J, Varadarajan BN, Becker JT, Rivadeneira F, Nalls MA, GraffRadford NR, Campion D, Auerbach S, Rice K, Hofman A, Jonsson PV, Schmidt H, Lathrop M, Mosley TH, Au R, Psaty BM, Uitterlinden AG, Farrer LA, Lumley T, Ruiz A, Williams J, Amouyel P, Younkin SG, Wolf PA, Launer LJ, Lopez OL, van Duijn CM, Breteler MM, JAMA. 2010;303:1832-1840.

[137] Lambert JC, Zelenika D, Hiltunen M, Chouraki V, Combarros O, Bullido MJ, Tognoni G, Fievet N, Boland A, Arosio B, Coto E, Del Zompo M, Mateo I, Frank-Garcia A, Helisalmi S, Porcellini E, Pilotto A, Forti P, Ferri R, Delepine M, Scarpini E, Siciliano G, Solfrizzi V, Sorbi S, Spalletta G, Ravaglia G, Valdivieso F, Alvarez V, Bosco P, Mancuso M, Panza F, Nacmias B, Bossu P, Piccardi P, Annoni G, Seripa D, Galimberti D, Licastro F, Lathrop M, Soininen H, Amouyel P, Neurobiol Aging. 2011;32:756 e711-755.

[138] Pasternak SH, Callahan JW, Mahuran DJ, J Alzheimers Dis. 2004;6:53-65.

[139] Lorenzen A, Samosh J, Vandewark K, Anborgh PH, Seah C, Magalhaes AC, Cregan SP, Ferguson SS, Pasternak SH, Mol Brain. 2010;3:11.

[140] Ma QL, Galasko DR, Ringman JM, Vinters HV, Edland SD, Pomakian J, Ubeda OJ, Rosario ER, Teter B, Frautschy SA, Cole GM, Arch Neurol. 2009;66:448-457.

[141] Pottier C, Hannequin D, Coutant S, Rovelet-Lecrux A, Wallon D, Rousseau S, Legallic $\mathrm{S}$, Paquet C, Bombois S, Pariente J, Thomas-Anterion C, Michon A, Croisile B, EtcharryBouyx F, Berr C, Dartigues JF, Amouyel P, Dauchel H, Boutoleau-Bretonniere C, Thauvin C, Frebourg T, Lambert JC, Campion D, Mol Psychiatry. 2012.

[142] Fjorback AW, Seaman M, Gustafsen C, Mehmedbasic A, Gokool S, Wu C, Militz D, Schmidt V, Madsen P, Nyengaard JR, Willnow TE, Christensen EI, Mobley WB, Nykjaer A, Andersen OM, J Neurosci. 2012;32:1467-1480.

[143] Hierro A, Rojas AL, Rojas R, Murthy N, Effantin G, Kajava AV, Steven AC, Bonifacino JS, Hurley JH, Nature. 2007;449:1063-1067.

[144] Bonifacino JS, Hurley JH, Curr Opin Cell Biol. 2008;20:427-436.

[145] Muhammad A, Flores I, Zhang H, Yu R, Staniszewski A, Planel E, Herman M, Ho L, Kreber R, Honig LS, Ganetzky B, Duff K, Arancio O, Small SA, Proc Natl Acad Sci U S A. 
2008;105:7327-7332.

[146] Lee J, Retamal C, Cuitino L, Caruano-Yzermans A, Shin JE, van Kerkhof P, Marzolo MP, Bu G, J Biol Chem. 2008;283:11501-11508.

[147] He X, Chang WP, Koelsch G, Tang J, FEBS Lett. 2002;524:183-187.

[148] Santosa C, Rasche S, Barakat A, Bellingham SA, Ho M, Tan J, Hill AF, Masters CL, McLean C, Evin G, Neurobiol Dis. 2011;43:176-183.

[149] Thathiah A, De Strooper B, Nat Rev Neurosci. 2011;12:73-87.

[150] Renner M, Lacor PN, Velasco PT, Xu J, Contractor A, Klein WL, Triller A, Neuron. 2010;66:739-754.

[151] Wang D, Yuen EY, Zhou Y, Yan Z, Xiang YK, J Biol Chem. 2011;286:31852-31863.

[152] Patel AN, Jhamandas JH, Expert Rev Mol Med. 2012;14:e2.

[153] Robert SJ, Zugaza JL, Fischmeister R, Gardier AM, Lezoualc'h F, J Biol Chem. 2001;276:44881-44888.

[154] Cho S, Hu Y, Exp Neurol. 2007;203:274-278.

[155] Maillet M, Robert SJ, Cacquevel M, Gastineau M, Vivien D, Bertoglio J, Zugaza JL, Fischmeister R, Lezoualc'h F, Nat Cell Biol. 2003;5:633-639.

[156] Bockaert J, Claeysen S, Compan V, Dumuis A, Curr Opin Pharmacol. 2011;11:87-93.

[157] Barthet G, Framery B, Gaven F, Pellissier L, Reiter E, Claeysen S, Bockaert J, Dumuis A, Mol Biol Cell. 2007;18:1979-1991.

[158] Ansanay H, Dumuis A, Sebben M, Bockaert J, Fagni L, Proc Natl Acad Sci U S A. 1995;92:6635-6639.

[159] Restivo L, Roman F, Dumuis A, Bockaert J, Marchetti E, Ammassari-Teule M, Neuropsychopharmacology. 2008;33:2427-2434.

[160] Johnson DE, Drummond E, Grimwood S, Sawant-Basak A, Miller E, Tseng E, McDowell LL, Vanase-Frawley MA, Fisher KE, Rubitski DM, Stutzman-Engwall KJ, Nelson RT, Horner WE, Gorczyca RR, Hajos M, Siok CJ, J Pharmacol Exp Ther. 2012.

[161] De Felice FG, Wasilewska-Sampaio AP, Barbosa AC, Gomes FC, Klein WL, Ferreira ST, Curr Alzheimer Res. 2007;4:263-271.

[162] Kojro E, Postina R, Buro C, Meiringer C, Gehrig-Burger K, Fahrenholz F, Faseb J. 2006;20:512-514.

[163] Rat D, Schmitt U, Tippmann F, Dewachter I, Theunis C, Wieczerzak E, Postina R, van Leuven F, Fahrenholz F, Kojro E, FASEB J. 2011;25:3208-3218.

[164] Diaz-Rodriguez E, Montero JC, Esparis-Ogando A, Yuste L, Pandiella A, Mol Biol Cell. 2002;13:2031-2044.

[165] Mills J, Laurent Charest D, Lam F, Beyreuther K, Ida N, Pelech SL, Reiner PB, J Neurosci. 1997; 17:9415-9422.

[166] Buxbaum JD, Gandy SE, Cicchetti P, Ehrlich ME, Czernik AJ, Fracasso RP, Ramabhadran TV, Unterbeck AJ, Greengard P, Proc Natl Acad Sci U S A. 1990;87:60036006.

[167] Caporaso GL, Gandy SE, Buxbaum JD, Ramabhadran TV, Greengard P, Proc Natl Acad Sci U S A. 1992;89:3055-3059.

[168] Buxbaum JD, Oishi M, Chen HI, Pinkas-Kramarski R, Jaffe EA, Gandy SE, Greengard P, Proc Natl Acad Sci U S A. 1992;89:10075-10078.

[169] Nitsch RM, Slack BE, Wurtman RJ, Growdon JH, Science. 1992;258:304-307.

[170] Levey AI, Kitt CA, Simonds WF, Price DL, Brann MR, J Neurosci. 1991;11:32183226 .

[171] Hung AY, Haass C, Nitsch RM, Qiu WQ, Citron M, Wurtman RJ, Growdon JH, Selkoe DJ, J Biol Chem. 1993;268:22959-22962.

[172] Davis AA, Fritz JJ, Wess J, Lah JJ, Levey AI, J Neurosci. 2010;30:4190-4196.

[173] Medeiros R, Kitazawa M, Caccamo A, Baglietto-Vargas D, Estrada-Hernandez T, 
Cribbs DH, Fisher A, LaFerla FM, Am J Pathol. 2011;179:980-991.

[174] Farber SA, Nitsch RM, Schulz JG, Wurtman RJ, J Neurosci. 1995;15:7442-7451.

[175] Nitsch RM, Deng M, Tennis M, Schoenfeld D, Growdon JH, Ann Neurol. 2000;48:913918.

[176] Caccamo A, Oddo S, Billings LM, Green KN, Martinez-Coria H, Fisher A, LaFerla FM, Neuron. 2006;49:671-682.

[177] Jones CK, Brady AE, Davis AA, Xiang Z, Bubser M, Tantawy MN, Kane AS, Bridges TM, Kennedy JP, Bradley SR, Peterson TE, Ansari MS, Baldwin RM, Kessler RM, Deutch AY, Lah JJ, Levey AI, Lindsley CW, Conn PJ, J Neurosci. 2008;28:10422-10433.

[178] Camden JM, Schrader AM, Camden RE, Gonzalez FA, Erb L, Seye CI, Weisman GA, J Biol Chem. 2005;280:18696-18702.

[179] Teng L, Zhao J, Wang F, Ma L, Pei G, Cell Res. 2010;20:138-153.

[180] Thathiah A, De Strooper B, Sci Signal. 2009;2:re8. 


\section{Figure legends}

\section{Figure 1: Schematic representation of APP processing.}

In the non-amyloidogenic pathway, $\alpha$-secretase $(\alpha$-sec) cleaves APP within the A $\beta$ domain determining the production of a soluble APP ectodomain, sAPP $\alpha$, and a membrane-anchored $\mathrm{C}$-terminal fragment, C83. The subsequent action of $\gamma$-secretase $(\gamma$-sec $)$ releases two peptides: the APP intracellular domain (AICD) and P3. In the amyloidogenic pathway, $\beta$-secretase ( $\beta$ sec) cleaves APP releasing the soluble sAPP $\beta$ and a C-terminal fragment (C99), which is in turn cleaved by $\gamma$-secretase to produce AICD and A $\beta$.

\section{Figure 2: Secretases involved in APP cleavage and interacting proteins modulating their trafficking and activity.}

ADAM10 ( $\alpha$-secretase) is a proenzyme converted to its mature form by the action of furin and/or PC7. A zinc ion binds to the catalytic domain once unmasked. SAP97, a synapseassociated protein, interacts with the intracellular domain and regulates the ADAM10 targeting to the glutamatergic synapse. The $\gamma$-secretase complex (PSEN1, Nct, PEN2 and APH1) shows interactions between PSEN1 and Arc, able to regulate the enzyme trafficking, and prostaglandin-E2 (PGE2), that modulates its activity. Abca-2 alters nicastrin (Nct) maturation, while Rer-1 negatively regulates the assembly of the $\gamma$-secretase complex competing with APH1. $\beta$-secretase trafficking is modulated by several proteins among which we find GGA1, GGA3 and ARF6 (see text for details). Cat, catalytic domain; Pro, prodomain; Dis, disintegrin domain; ICD, intracellular domain

\section{Figure 3:APP trafficking}

APP is transported via the constitutive secretary pathway from the ER, trough the Golgi and the TGN to the plasma membrane. ADAM10 is matured by removal of its pro-domain in the TGN and cleaves APP at the cell surface to release sAPP $\alpha$. Once it reaches the plasma membrane, APP is quickly internalized in clathrin-coated vesicles. Interactions with lipoprotein receptors such as LRP1 (see text) via the adaptor Fe65 can induce a faster internalization. $\beta$-Secretase (BACE1) is endocyted via a different route involving the small GTPase ARF6. APP and $\beta$-secretase can meet in the endosomal compartment, and be transported back in the TGN via the retromer complex. Indeed, the retromer (VPS35 subunit) binds the FANSHY motif of SorLA, thus regulates the sorting of APP, or binds to BACE1 and traffic the cargos in the TGN. BACE1 have access to direct route from the TGN to the endosomes via GGA1 and GGA3 proteins. A similar route involving the adaptor AP-4 can be followed by APP to reach endosomes directly from the TGN. $\gamma$-Secretase can cleave APP in the endosomal/lysosomal compartment, leading to $A \beta$ peptide production. Finally, the interaction of APP with FBL2, a component of the E3 ubiquitin ligase complex, leads to ubiquitination of APP and consequently, inhibition of cell surface APP endocytosis and promotion of intracellular APP degradation (see text for details).

\section{Figure 4: Detail of APP intracellular domain.}

The APP sequences interacting with proteins modulating APP trafficking and activity are highlighted. The VTPEER sequence (667-672) is implicated in the control of the interaction between the YENPTY sequence (682-687) and Fe65. Numerous other proteins are interacting with the YENPTY, among those are members of the X11 family (Mints) and Jip family, Dab1, SNX17 and SorLA. Finally, AP-4 binds to the YKFFE region (687-691) and regulates the trafficking of APP from the Golgi to the endosomes (see text for details). 
Figure 5: GPCRs modulating APP processing and A $\beta$ production.

Two groups of GPCRs modulate APP processing. The first group contains GPCRs which stimulate the non-amyloidogenic pathway. Among those GPCRs, muscarinic $\mathrm{M}_{1}$ receptors, $\mathrm{P}_{2} \mathrm{Y}_{2}$ receptors, 5- $\mathrm{HT}_{4}$ receptors and $\mathrm{PAC}_{1}$ receptors stimulate sAPP $\alpha$ production through a PKC activation, the concentration of extracellular calcium, the cAMP/EPAC pathway and the IP3/MAPK pathway, respectively. The second group contains GPCRs, which increase the amyloidogenic pathway. GPR3, an, orphan GPCR interacts with $\gamma$-secretase and stimulates its activity. $\beta_{2}-\mathrm{AR}$ and $\mathrm{DOR}$, when internalized in endosomes following their activation, stimulate the co-internalization of the $\gamma$-secretase $\left(\beta_{2}-\mathrm{AR}\right)$ and both the $\gamma$-secretase and $\beta$ secretase (DOR), a process which increases $A \beta$ production. Furthermore, A $\beta$ oligomers trigger an abnormal clustering of mGlu5 receptors, which is synaptotoxic (see text for details). 


\begin{tabular}{|c|c|c|c|}
\hline & Activity & Trafficking and assembly & Synthesis \\
\hline$\alpha$-secretase & $\begin{array}{l}\text { Furin, PC-7, PKC activators, } \\
\text { Cholesterol, 5-HT, R }\end{array}$ & $\begin{array}{l}\text { SAP-97, M } \mathrm{M}_{1} \text { receptors, } \\
\text { acetylcholinesterase inhibitors }\end{array}$ & SIRT-1, retinoic acid \\
\hline$\beta$-secretase & $\begin{array}{l}\text { reticulon/NOGO proteins, } \\
\text { sAPP } \alpha\end{array}$ & $\begin{array}{l}\text { GGA1, GGA3, ARF6, } \\
\text { retromers, sortilin, } \\
\text { reticulon/NOGO proteins }\end{array}$ & $\begin{array}{l}\mathrm{A} \beta \text {, hypoxia, oxidative stress, } \\
\text { traumatic brain injury, HSV1 }\end{array}$ \\
\hline$\gamma$-secretase & $\begin{array}{l}\text { Prostaglandin E2, } \beta_{2}-\mathrm{AR}, \\
\text { GSMs, TMP21, basigin, } \\
\text { Abca- } 2, \text { gSAP }\end{array}$ & $\begin{array}{l}\text { Arc, Rer-1, orphan receptor } \\
\text { GPR3 }\end{array}$ & Wnt-1, p53 \\
\hline
\end{tabular}

Table1: Summary of $\alpha$-, $\beta$ - and $\gamma$-secretase modulators. 


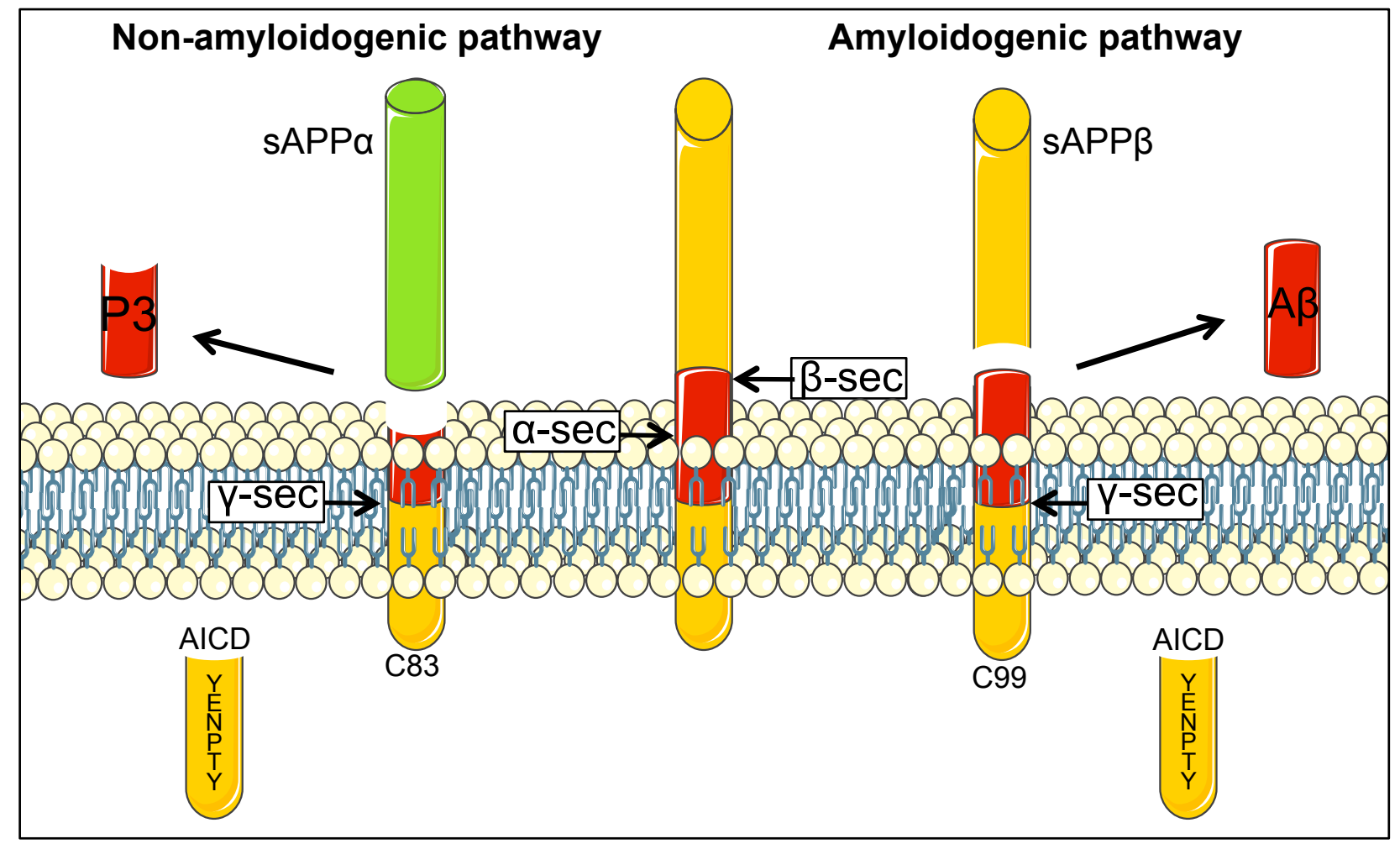

Figure 1 




Figure 2 


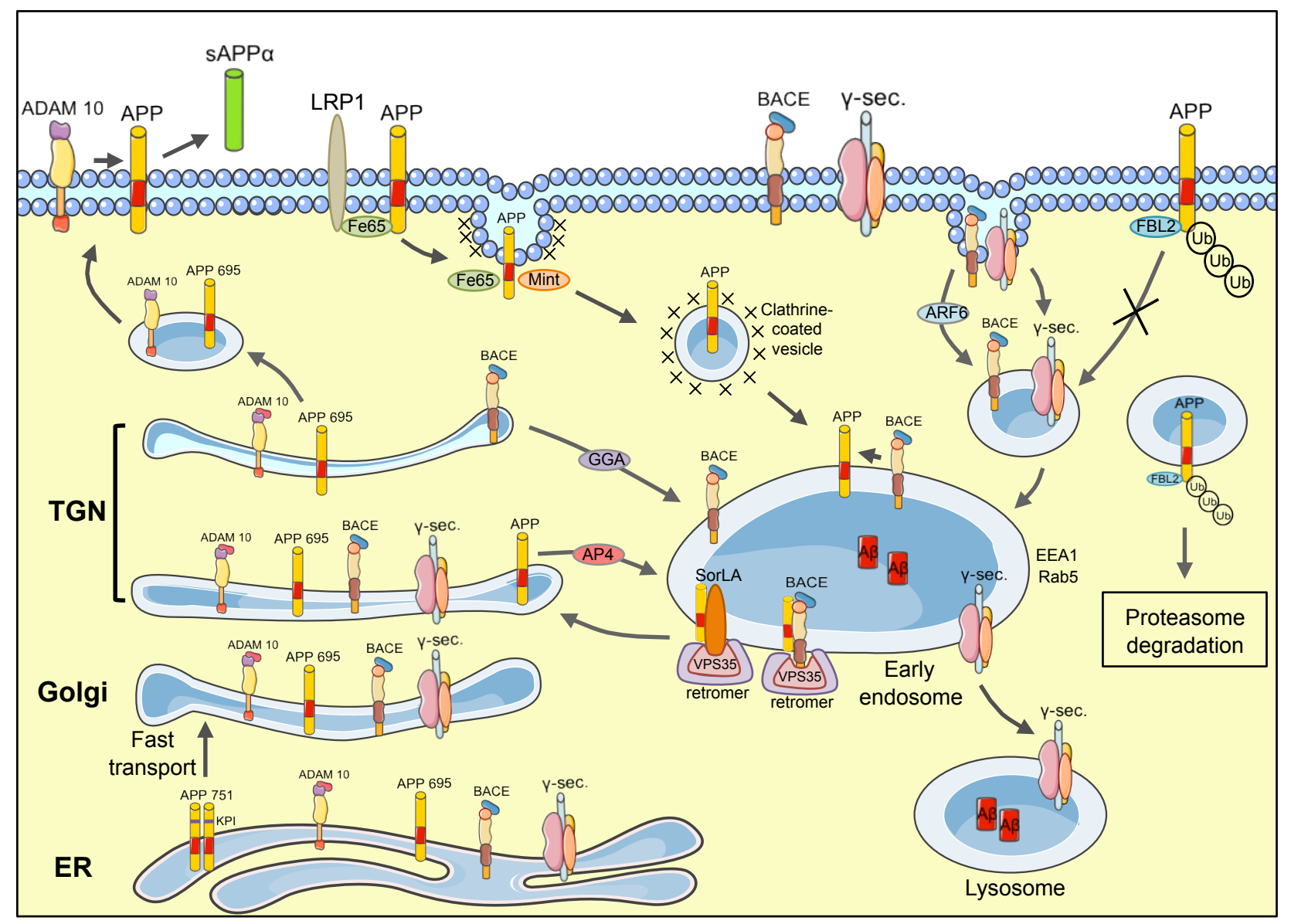

Figure 3 


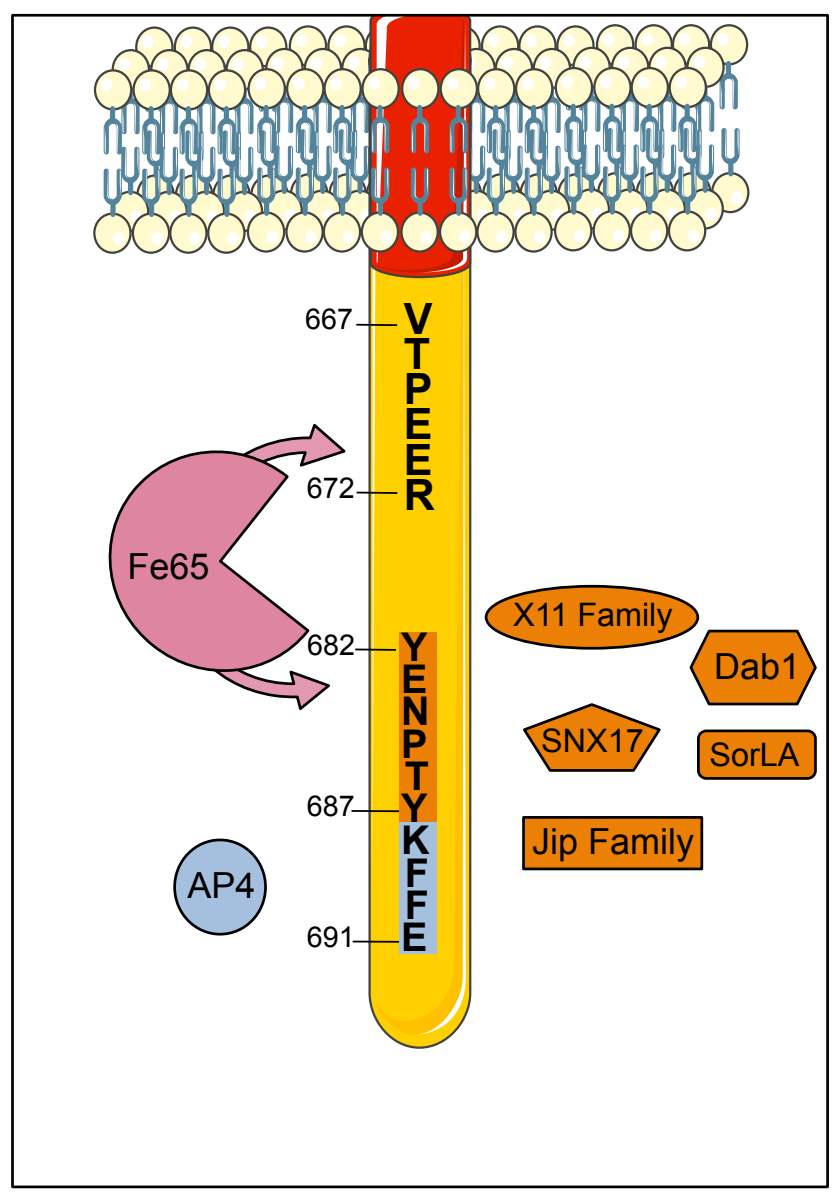

Figure 4 


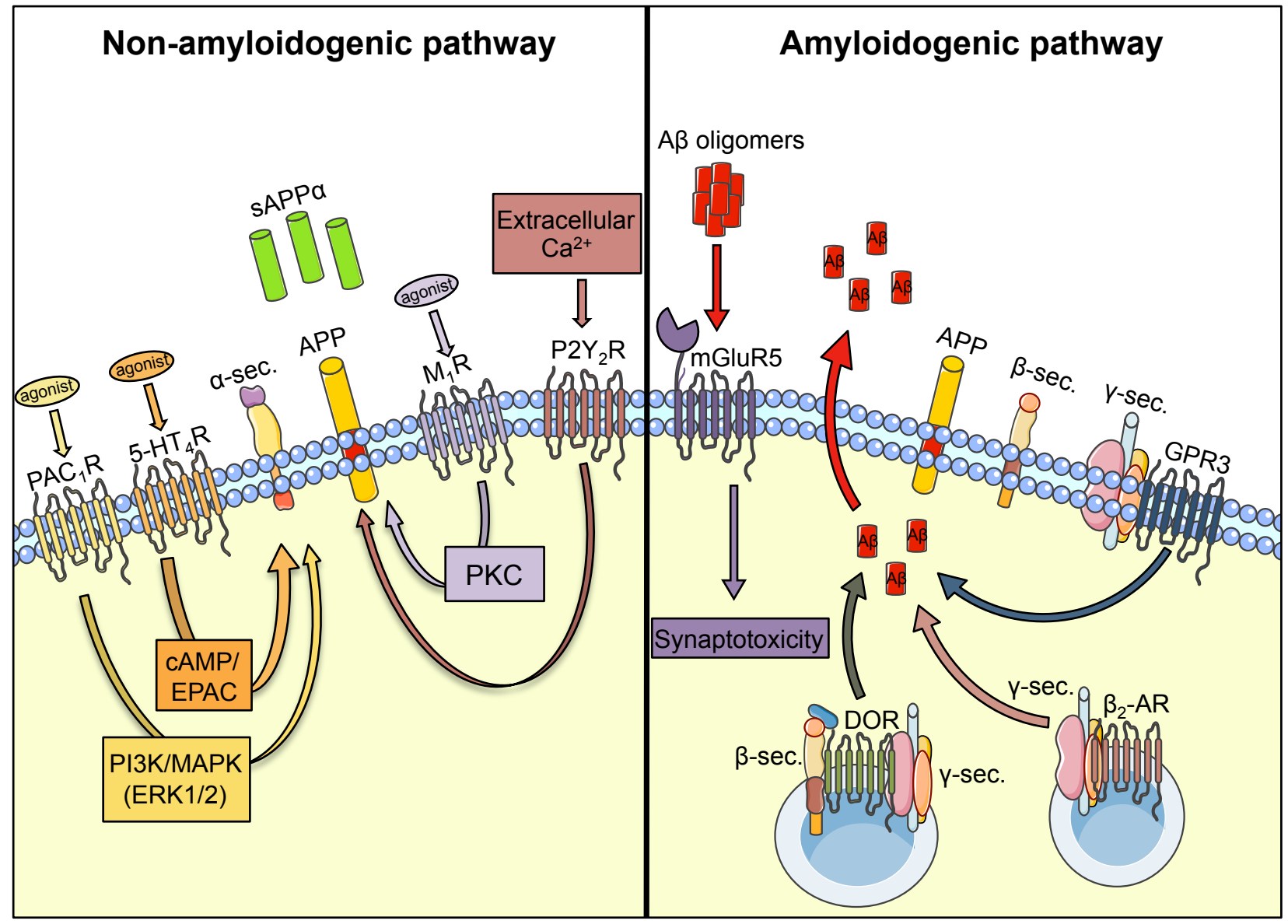

Figure 5 